\title{
MENYIBAK MAKNA KARIKATUR MEDIA MASSA
}

\author{
Acan Mahdi
}

\begin{abstract}
Abstrak
Tulisan ini berangkat dari keinginan untuk "menyibak" makna dan ideologi yang ada dibalik karikatur suratkabar Pontianak Post mengenai wacana kenaikan harga bahan bakar minyak di awal tahun 2012. Penelitian ini berkepentingan menanyakan gambaran atau citra yang bagaimanakah yang ditonjolkan karikatur tersebut dalam pewacanaannya mengenai kenaikan harga bahan minyak, dan bagaimanakah karikatur tersebut merepresentasikan keberpihakan pada ideologi atau kepentingan tertentu? Hasil analisis menyimpulkan bahwa gambaran atau citra yang ingin disampaikan karikatur suratkabar Pontianak Post mengenai wacana kenaikan harga bahan bakar minyak adalah bahwa, 1). Kenaikan harga BBM adalah penderitaan bagi masyarakat kecil; 2). Kenaikan harga BBM menyebabkan kenaikan harga-harga; 3). Kenaikan harga BBM harus dilawan; dan 4).

Penguasa tidak memiliki sense of crisis. Ideologi demokrasi diyakini mempengaruhi teks karikatur suratkabar Pontianak Post dalam mewacanakan rencana pemerintah untuk menaikan harga bahan bakar minyak. Karena, dengan ideologi demokrasi yang mereka anut memungkinkan mereka untuk memilih atau bersikap berseberangan atau mengambil sikap "konfrontasi" terhadap rencana pemerintah SBY untuk menaikkan harga bahan bakar minyak.
\end{abstract}

Kata Kunci: Makna Kultural, Media Massa, Karikatur

\section{A. Muqaddimah}

Secara teknis memang banyak faktor yang mempengaruhi isi media massa. Pamela J. Shoemaker dan Stephen D. Reese (Agus Sudibyo, 2001: 7) mencatat ada empat hal yang mempengaruhi pengambilan keputusan redaksi yaitu:
Pertama, faktor individual. Faktor ini berhubungan dengan latar belakang profesional dari pengelola media. Level individual melihat bagaimana pengaruh aspek-aspek personal dari pengelola media mempengaruhi pemberitaan yang akan ditampilkan kepada khalayak. Latar belakang individu seperti jenis kelamin, umur, atau agama, sedikit banyak mempengaruhi apa yang ditampilkan 
media. Kenapa media tertentu cenderung memarjinalkan wanita atau kenapa agama Islam di Maluku digambarkan secara buruk oleh media tertentu? Kalau pendekatan individual yang diambil, penjelasannya adalah karena aspek personalitas dari wartawan yang akan mempengaruhi pemberitaan. Aspek personal tersebut, jelas Agus, secara hipotetik mempangaruhi skema pemahaman pengelola media. Wartawan yang beragama Islam secara hipotetik lebih berempati dengan kondisi warga Islam di Maluku atau Poso dibandingkan kelompok Kristen. Atau wartawan lokal Kalimantan Barat lebih berempati dengan warga Dayak (asli) dibandingkan warga pendatang Madura ketika memberitakan konflik etnis di Kalimantan Barat.

Kedua, level rutinitas media. Rutinitas media berhubungan dengan mekanisme dan proses penentuan berita. Setiap media umumnya mempunyai ukuran tersendiri tentang apa yang disebut berita, apa ciri-ciri yang baik, atau apa kriteria kelayakan berita. Ukuran tersebut adalah rutinitas yang berlangsung tiap hari dan menjadi prosedur standar bagi pengelola media yang berada di dalamnya. Rutinitas media juga berhubungan dengan mekanisme bagaimana berita dibentuk. Ketika ada sebuah peristiwa penting yang harus diliput, bagaimana pendelegasian tugasnya, melalui proses tangan siapa saja sebuah tulisan sebelum sampai keproses cetak, siapa penulisnya, siapa editornya, dan seterusnya. Sebagai mekanisme yang menjelaskan bagaimana berita diproduksi, rutinitas media karenanya mempengaruhi bagaimana wujud akhir sebuah berita.

Ketiga, level organisasi. Level organinisasi berhubungan dengan struktur organisasi yang secara hipatetik mempengaruhi pemberitaan. Pengelola media bukan orang yang tunggal yang ada dalam organisasi berita, ia sebaliknya hanya bagian kecil dari organisasi berita itu sendiri. Masingmasing komponen dalam organisasi bisa jadi mempunyai kepentingan sendirisendiri. Di dalam organisasi media, misalnya selain bagian redaksi ada juga bagian pemasaran, bagian iklan, bagian sirkulasi, bagian umum dan seterusnya. Masing-masing bagian tersebut tidak selalu sejalan. Mereka mempunyai tujuan dan target masing-masing, sekaligus strategi yang berbeda untuk mewujudkan terget tersebut. Bagian redaksi misalnya menginginkan agar berita tertentu yang disajikan, tetapi bagian sirkulasi menginginkan agar berita lain yang ditonjolkan karena terbukti dapat menaikkan penjualan. 
Setiap organisasi berita, selain mempunyai banyak elemen juga mempunyai tujuan dan filosofi organisasi sendiri, berbagai elemen tersebut mempengaruhi seharsnya wartawan bersikap, dan bagaimana juga seharusnya peristiwa disajikan dalam berita.

Keempat. Level ekstramedia. Level ini dihubungkan dengan faktor lingkungan di luar media. Meskipun di luar organisasi media, hal-hal di luar organisasi media ini sedikit banyak dalam banyak kasus mempengaruhi pemberitaan media. Ada beberapa faktor yang termasuk dalam lingkungan di luar media, yaitu, sumber berita, sumber penghasilan berita, pihak eksternal seperti pemerintah dan lingkungan bisnis, dan ideologi.

Keputusan menurunkan karikatur seperti apa dan bagaimana yang harus dibaca dan dilihat masyarakat adalah keputusan redaksi, yang tentu melalui pertimbangan-pertimbangan yang tentu merepresentasikan sikap dan ideologi yang dianut oleh media massa suratkabar termasuk suratkabar Pontianak Post. Tulisan ini berkepentingan mengungkap, pertama gambaran atau citra yang bagaimanakah yang ditonjolkan pada karikatur wacana kenaikan harga bahan bakar minyak pada suratkabar Pontianak Post. Kedua,
Bagaimanakah karikatur tersebut merepresentasikan keberpihakan pada ideologi atau kepentingan tertentu?

1. Karikatur Pontianak Post, 1 Maret 2012

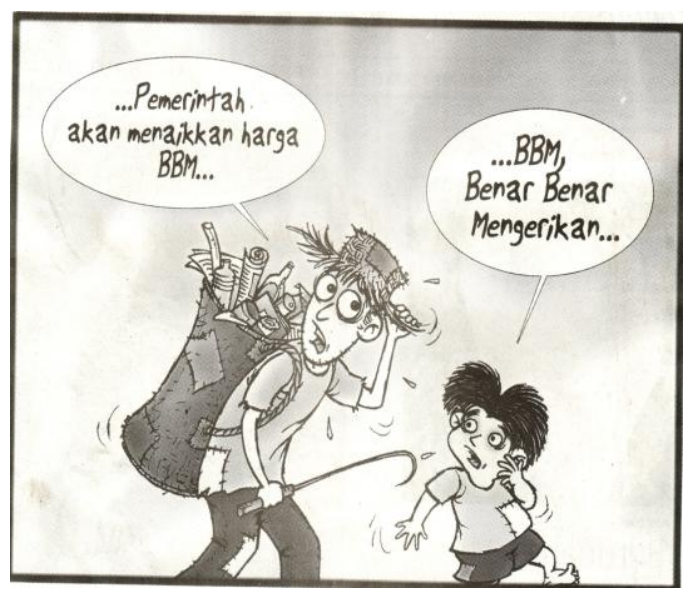

Sumber: Pontianak Post, Kamis 1 Maret 2012

Tabel 1. Sebaran Tanda pada Gambar 1

\begin{tabular}{|c|c|c|}
\hline Dimensi & $\begin{array}{l}\text { Ditandai } \\
\text { dengan }\end{array}$ & Asosiasi \\
\hline Icon & $\begin{array}{ll}\text { - } & \text { Gambar dua } \\
\text { orang } \\
\text { manusia; } \\
\text { - Gambar } \\
\text { ambinan; } \\
\text { - } \text { Gambar topi; } \\
\text { - } \text { Gamar } \\
\text { Pengait } \\
\text { sampah. }\end{array}$ & $\begin{array}{l}\text { Menyerupai } \\
\text { bentuk asli } \\
\text { Menyerupai } \\
\text { bentuk asli } \\
\text { Menyerupai } \\
\text { bentuk asli } \\
\text { Menyerupai } \\
\text { bentuk asli }\end{array}$ \\
\hline Indeks & 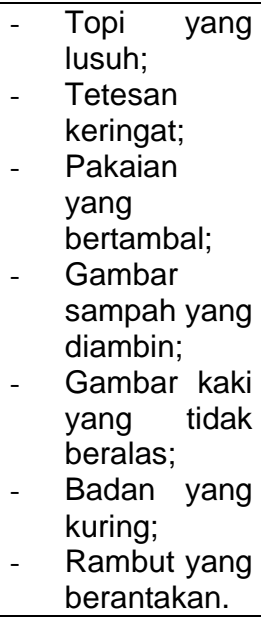 & $\begin{array}{l}\text { Penggambaran } \\
\text { orang kecil } \\
\text { Penggambaran } \\
\text { lelah atau } \\
\text { sedang bekerja } \\
\text { keras } \\
\text { Penggambaran } \\
\text { oang kecil } \\
\text { Pengambaran } \\
\text { pemulung } \\
\text { Penggambaran } \\
\text { orang kecil } \\
\text { Penggambaran } \\
\text { orang } \\
\text { miskin/kecil } \\
\text { Penggambaran } \\
\text { rambut orang }\end{array}$ \\
\hline
\end{tabular}




\begin{tabular}{|c|c|c|}
\hline & & kecil \\
\hline Simbol & $\begin{array}{l}\text { Visualisasi } \\
\text { kegelap-gelapan } \\
\text { pada latar }\end{array}$ & $\begin{array}{l}\text { Penggambaran } \\
\text { efek } \\
\text { menakutkan } \\
\text { atau } \\
\text { mengerikan }\end{array}$ \\
\hline Caption & $\begin{array}{ll}\text { 1. } & \text {...pemerintah } \\
\text { akan } \\
\text { menaikan } \\
\text { harga BBM... } \\
\text { 2. } \\
\text {...BBM } \\
\text { benar-benar } \\
\text { mengerikan } \\
\text {... }\end{array}$ & $\begin{array}{l}\text { Topik yang } \\
\text { dibicarakan } \\
\text { Mengarahkan } \\
\text { bagaimana kita } \\
\text { harus berfikir } \\
\text { tentang } \\
\text { wacana } \\
\text { kenaikan harga } \\
\text { bahan bakar } \\
\text { minyak. }\end{array}$ \\
\hline
\end{tabular}

Keseluruhan gambar dibuat pada latar yang putih kegelap-gelapan. Latar putih terlihat dari bawah hingga pertengahan, jika ditarik dari bawah. Sementara rona atau efek kegelapan dibubuhi pada sisi kanan atas hingga hampir sisi kiri gambar. Efek putih kegelap-gelapan adalah upaya untuk menggambarkan suasana mengerikan pada gambar. Warna gelap atau hitam dalam konteks budaya adalah simbol yang bermakna hal-hal yang jelek atau menakutkan. Misalnya, hantu yang diasosiasikan berwarna hitam. Tokohtokoh jahat dalam film kita selalu digambarkan berpakaian hitam - dan lawannya tokoh yang baik selalu digambarkan mengenakan pakaian putih. Atau orang takut keluar ditengah malam, karena gelap - tidak ada penerangan. Secara budaya warna hitam atau kegelap-gelapan diartikulasikan sebagai hal-hal yang jelek atau jahat. Karena itu dia mengerikan. Penggunaan efek kegelap-gelapan atau kehitam-hitaman dalam gambar ini agar pembaca teks ini mendapatkan asosiasi mengerikan dari gambar.

Secara visual gambar 1 terdiri dari karikatural dua orang pemulung yang sedang bekerja yaitu memungut sampah atau barang bekas. Dua karikatur manusia ini adalah ikon pemulung. Boleh jadi dua orang pemulung ini adalah seorang ayah dan anak lelakinya. Sang ayah sedang membawa atau sedang mengambin tempat sampah di belakangnya. Di tangan kanannya terdapat pengkait yang digunakan untuk mengait sampah. Sang ayah sedang mengenakan topi yang kelihatannya sudah usang, dengan ujung-ujung anyaman yang sudah tidak benbentuk lagi. Selain itu sang ayah juga digambarkan mengenakan pakaian, topi dan ambinan yang semuanya betambal atau ada tambalannya. $\mathrm{Di}$ dalam ambinannya digambarkan terdapat berbagai macam barang bekas atau sampah, seperti botol bekas, gulungan kertas dan lain-lain.

Topi yang usang dan bertambal, kemudian baju dan celana serta ambinan yang bertambal adalah indeks dari orang yang tidak berpunya, atau orang kecil secara ekonomi - jika tidak mau mengetakan orang miskin. Indeks kemiskinan ini mengarahkan pembaca 
untuk mendapatkan persepsi bahwa ikon dua orang manusia pada gambar adalah orang miskin atau masyarakat kecil.

Sedangkan si anak berada persis di sisi kiri ayahnya, dengan wajah seolah menatap ayahnya. Digambarkan si anak mengenakan celana pendek dan baju kaos oblong yang juga terdapat tambalan. Si anak digambarkan dengan menggunakan kaos oblong dan celana pendek, dan tidak beralas kaki, sepatu atau sandal. Digambarkan juga rambut si anak berdiri dan acak-acakan seolah tak terurus. Seperti pada sang ayah, tambalan yang terdapat paka pakaian, rambut yang berdiri dan telapak kaki yang tidak beralas merupakan indeks atau gambaran orang tak berpunya.

Secara visual juga digambarkan tetesan keringat yang beterbangan di antara gambar ayah dan anak. Tidak jelas keringat ini dari siapa sumbernya. Namun dia ada di antara kedua manusia dalam gambar ini. Keringat, selalu berasosiasi pada kerja keras, atau secara biologis badan sedang terkuras karena bekerja atau berfikir. Keringat, dalam gambar ini adalah indeks atau gambaran dari kerja keras. Dari gambar ini, kita mendapatkan gambaran seolahseolah dua ikon pemulung ini sedang bekerja keras untuk mempertahankan hidup.
Secara verbal terdapat dua caption pada gambar 1 Caption pertama digambarkan persis di atas sang ayah. Caption ini bertuluskan "...Pemerintah akan menaikkan harga BBM...". Pada sisi bawah figura yang membentuk caption ini terlihat panah yang mengarah pada sang ayah. Gambar ini menunjukkan seolah-olah kata-kata yang terdapat pada caption itu keluar dari mulut sang ayah.

Caption ke dua berada persis di atas sang anak. Pada sisi bawah figura yang mem-frame caption terdapat panah yang menunjuk pada si anak. Caption ini bertuliskan "...BBM Benar Benar Mengerikan...". Secara kasat mata kita dapat berkesimpulan bahwa caption ini adalah kata-kata yang keluar dari mulut sang anak.

Caption pada gambar berfungsi mengarahkan persepsi pembaca pada makna yang diinginkan oleh pembuat gambar. Jika kita hilangkan caption-nya, maka yang terjadi adalah gambar "telanjang", yang kemungkinan melahirkan banyak asosiasi. Orang bebas menafsirkan gambar. Dengan adanya caption ini pembaca mendapatkan satu asosiasi yang diinginkan oleh pembuat gambar. Dengan kata lain caption berfungsi mem-frame pembaca pada asosiasi tertentu. Sehingga pembaca atau siapa yang melihat gambar tidak lagi bingung menentukan asosiasi apa yang harus diberikan pada gambar. 
2. Karikatur Suratkabar Pontianak Post, 3 Maret 2012

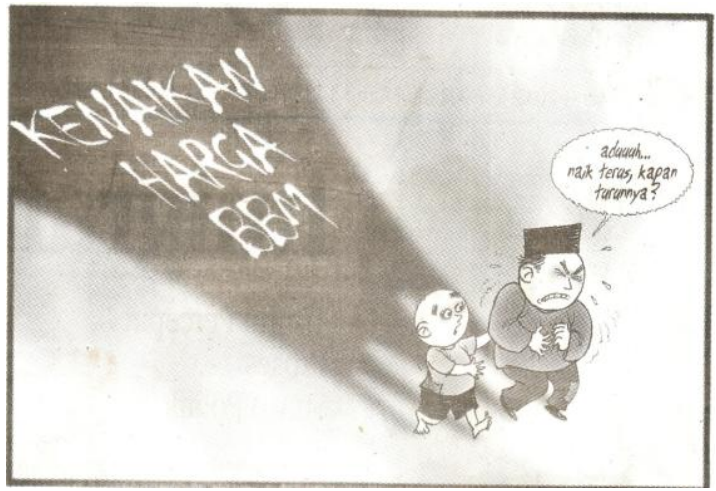

Sumber: Pontianak Post, Sabtu 3 Maret 2012

Tabel 2. Sebaran Tanda pada Gambar 2

\begin{tabular}{|c|c|c|}
\hline Dimensi & Ditandai dengan & Asosiasi \\
\hline Icon & $\begin{array}{l}\text { Dua orang } \\
\text { Manusia }\end{array}$ & $\begin{array}{l}\text { Menyerupai } \\
\text { bentuk asli } \\
\text { manusia }\end{array}$ \\
\hline Indeks & $\begin{array}{ll}\text { - } & \text { Wajah } \\
\text { meringis; } \\
\text { - } \quad \text { Bentuk badan } \\
\text { yang seperti } \\
\text { menggigil; } \\
\text { - } \quad \text { Pakaian yang } \\
\text { bertambal; } \\
\text { - Tetesan } \\
\text { keringat; } \\
\text { - Kaki yang } \\
\text { tidak beralas }\end{array}$ & $\begin{array}{l}\text { Penggambaran } \\
\text { seseorang } \\
\text { yang sedang } \\
\text { kesakitan } \\
\text { Penggambaran } \\
\text { seseorang } \\
\text { yang lagi sakit } \\
\text { atau kesakitan } \\
\text { Penggambaran } \\
\text { orang } \\
\text { kecil/miskin } \\
\text { Penggambaran } \\
\text { seseorang } \\
\text { yang sedang } \\
\text { bekerja keras } \\
\text { Penggambaran } \\
\text { orang } \\
\text { kecil/orang tak } \\
\text { berpunya }\end{array}$ \\
\hline Simbol & $\begin{array}{l}\text { Visualisasi } \\
\text { kekelap-gelapan } \\
\text { pada bayangan } \\
\text { manusia }\end{array}$ & $\begin{array}{l}\text { Penggambaran } \\
\text { untuk } \\
\text { mendapatkan } \\
\text { kesan } \\
\text { menyeramkan } \\
\text { atau } \\
\text { menakutkan. }\end{array}$ \\
\hline Caption & $\begin{array}{ll}\text { 1. } & \text { Kenaikan } \\
\text { Harga BBM } \\
\text { 2. } \\
\text { aduuh...naik } \\
\text { terus, kapan } \\
\text { turunnya? }\end{array}$ & $\begin{array}{l}\text { Topik yang } \\
\text { dibicarakan } \\
\text { Mengarahkan } \\
\text { bagaimana kita } \\
\text { harus berfikir } \\
\text { tentang } \\
\text { wacana } \\
\end{array}$ \\
\hline
\end{tabular}

\begin{tabular}{|l|l|l|}
\hline & $\begin{array}{l}\text { kenaikan harga } \\
\text { bahan bakar } \\
\text { minyak. }\end{array}$ \\
\hline
\end{tabular}

Gambar 2 secara visual digambarkan dua orang manusia, mungkin anak dan ayahnya. Sang ayah digambarkan dengan wajah meringis. Digambarkan pula sang ayah mengenakan peci, berbaju kaos oblong lengan panjang dan celana panjang. Sang ayah digambarkan seperti menggigil ketakutan atau sakit. Sedangkan si anak digambarkan memegang tangan ayahnya. Keduanya digambarkan seperti beriringan. Digambarkan pula si anak dengan kepala botak, menggunakan kaos oblong lengan pendek dan celana pendek. Si anak digambarkan tidak menggunakan alas kaki.

Gambar dua manusia ini adalah ikon dari manusia. Ikon anak dan ayah dalam gambar ini sama-sama menggunakan pakaian yang bertambal. Tambalan pada pakaian yang dikenakan adalah indeks, yang menggambarkan orang kecil atau orang tak berpunya. Anak yang tidak beralas kaki juga indeks dari anak orang tak berpunya. Selain itu, wajah yang meringis dan bentuk badan yang seperti menggil merupakan indeks yang menggambarkan kesakitan atau mengerikan. 
Visualisasi yang lain digambarkan pula bahwa kedua orang ini memiliki bayangan hitam yang seolah membentuk latar. Semakin jauh bayangan ini semakin membesar, sehingga menampakkan gambaran seolah-olah matahari berada persis dihadapan kedua orang ini. Gambaran hitam yang terbentuk dari bayangan ini adalah simbol kengerian atau ketakutan. Hitam atau gelap adalah simbol kejahatan atau hal-hal yang jelek, yang menakutkan. Gambaran hitam pada gambaran ini memperlihatkan bahwa, kesan menakutkan itu selalu membayangi di mana saja kedua manusia itu berada.

Selain itu, persis disamping kiri dan kanan wajah sang ayah digambarkan tetesan keringat yang berterbangan. Keringat yang yang beterbangan adalah indeks bahwa si ayah sedang bekerja keras menahan atau melawan sesuatu. Gambaran yang didapat adalah bahwa seolah-seolah sang ayah berkeringat mempertahankan hidup.

Secara keseluruhan, gambar dilatari oleh warna putih. Bayangan hitam kedua orang pada gambar membentuk aksen tersendiri, memberikan efek lain pada gambar secara keseluruhan. Sehingga, dengan mata telanjang dapat kita beri kesimpulan bahwa gambar ini terdiri dari warna hitam dan putih.
Penggambaran hitam pada visual ini menampakkan kesan mengerikan atau menakutkan bagi pembaca. Ini adalah makna budaya, bahwa warna hitam selalu diasosiasikan dengan hal-hal yang mengerikan atau menakutkan. Hitam atau kegelap-gelapan adalah simbol budaya yang selalu bermakna menakutkan atau hal-hal yang tidak baik.

Pada tanda-tanda verbal, gambar ini terdiri dari dua caption. Caption yang pertama persis di atas sang ayah. Caption ini berbunyi "aduuuh... naik terus, kapan turunnya". Pada sisi yang paling bawah fugura yang membentuk caption menunjuk pada sang ayah. Gambaran ini menunjuk bahwa kata-kata yang ada pada caption adalah kata-kata yang keluar dari mulut sang ayah.

Sedangkan caption yang kedua terlatak pada efek hitam yang terbentuk dari bayangan dua ikon anak dan ayah pada gambar. Caption ini berbunyi "KENAIKAN HARGA BBM". Caption ini mempertegas bahwa bayangan hitam yang bernama "KENAIKAN HARGA BBM" adalah hantu yang selalu menakutkan bagi masyarakat kecil. 
3. Karikatur Suratkabar Pontianak Post, 6 Maret 2012

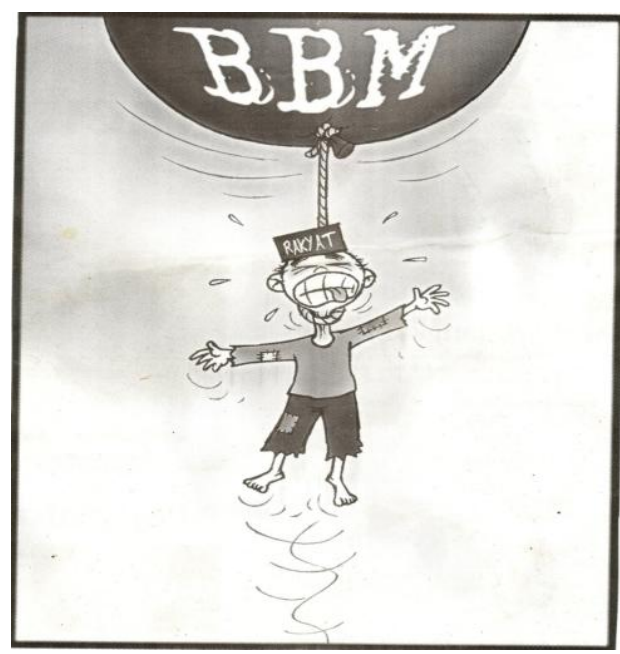

Sumber: Pontianak

Post, Selasa 6

Maret 2012

\begin{tabular}{|c|c|c|}
\hline & & $\begin{array}{l}\text { sedang bekerja } \\
\text { keras } \\
\text { Penggambaran } \\
\text { orang } \\
\text { kecil/orang tak } \\
\text { berpunya }\end{array}$ \\
\hline Simbol & $\begin{array}{ll}\text { - } & \text { Visualisasi } \\
\text { kekelap- } \\
\text { gelapan } \\
\text { pada latar } \\
\text { - } \quad \text { visualisasi } \\
\text { hitam pada } \\
\text { balon }\end{array}$ & $\begin{array}{l}\text { Penggambaran } \\
\text { untuk } \\
\text { mendapatkan } \\
\text { kesan } \\
\text { menyeramkan } \\
\text { atau } \\
\text { menakutkan. } \\
\text { Penggambaran } \\
\text { untuk } \\
\text { mendapatkan } \\
\text { kesan } \\
\text { menyeramkan } \\
\text { atau } \\
\text { menakutkan. }\end{array}$ \\
\hline Caption & $\begin{array}{l}\text { - tulisan "BBM", } \\
\text { pada balon } \\
\text { - } \quad \text { tulisan } \\
\text { "Rakyat" } \\
\text { pada } \\
\text { manusia }\end{array}$ & $\begin{array}{l}\text { Menceritakan } \\
\text { BBM yang } \\
\text { mealmbung } \\
\text { tinggi } \\
\text { Mengarahkan } \\
\text { bagaimana kita } \\
\text { harus berfikir } \\
\text { tentang wacana } \\
\text { kenaikan harga } \\
\text { bahan bakar } \\
\text { minyak. }\end{array}$ \\
\hline
\end{tabular}

Gambar 3 terdiri dari dua

Tabel 3. Sebaran Tanda pada Gambar 3

\begin{tabular}{|c|c|c|}
\hline Dimensi & $\begin{array}{c}\text { Ditandai } \\
\text { dengan }\end{array}$ & Asosiasi \\
\hline Icon & $\begin{array}{ll}\text { - } & \text { seorang } \\
& \text { Manusia } \\
- & \text { sebuah } \\
& \text { balon }\end{array}$ & $\begin{array}{l}\text { Menyerupai } \\
\text { bentuk asli } \\
\text { manusia } \\
\text { Menyerupai } \\
\text { balon }\end{array}$ \\
\hline Indeks & $\begin{array}{ll}\text { - } & \text { Wajah } \\
& \text { meringis; } \\
\text { - } & \text { lidah yang } \\
& \text { terjulur; } \\
\text { - } & \text { Pakaian } \\
& \text { yang } \\
\text { bertambal; } & \text { Tetesan } \\
\text { - } & \text { keringat; } \\
\text { - Kaki yang } \\
\text { tidak } \\
\text { beralas }\end{array}$ & $\begin{array}{l}\text { Penggambaran } \\
\text { seseorang yang } \\
\text { sedang } \\
\text { kesakitan } \\
\text { Penggambaran } \\
\text { seseorang yang } \\
\text { lagi sakit atau } \\
\text { kesakitan, atau } \\
\text { bahkan } \\
\text { meninggal } \\
\text { karena sakit } \\
\text { yang amat } \\
\text { pedih. } \\
\text { Penggambaran } \\
\text { orang } \\
\text { kecil/miskin } \\
\text { Penggambaran } \\
\text { seseorang yang }\end{array}$ \\
\hline
\end{tabular}

visualisasi yaitu seorang manusia yang tergantung dan sebuah balon raksasa. Digambarkan seorang manusia ini mati tergantung dengan seutas tali yang menjerat di leher dan terhubung dengan balon gas yang berada persis di atasnya. Secara gamblang kita dapat menafsirkan bahwa orang tersebut mati tergantung oleh tali yang terikat pada balon dan menjerat leher orang tersebut. Manusia yang digambarkan seolah-olah kesakitan atau bahkan meninggal dunia karena jeratan tali yang ada di balon tersebut. Manusia ini digambarkan dengan lidah yang terjulur ke luar. Selain itu dapat 
pula kita lihat pakaian manusia tersebut mengenakan kaos oblong dan celana panjang yang dipotong. Secara kasat mata kita dapat menilai manusia yang digambarkan tersebut berbadan kurus. Sobek dan Tambalan dilukiskan terdapat pada baju dan celana yang dikenakan. Tanda yang lain juga tampak dari butiran keringat yang beterbangan persis disamping kiri dan kanan wajah manusia tersebut. Selain itu tidak terdapat alas kaki yang dikenakan oleh manusia yang digambarkan.

Visualisasi balon adalah ikon dari balon. Dan visualisasi manusia adalah ikon dari seorang manusia. Gambaran manusia kurus adalah indeks kemiskinan atau ketidakberdayaan. Digambarkan bahwa manusia yang menggantungkan diri atau mati tergantung tersebut dalam keadaan miskin terlihat dari badannya yang kurus-kering. Celana dan baju yang sobek dan bertambal adalah indeks kemiskinan dan gambaran orang kecil secara ekonomi. Gambaran ini memberikan arahan bahwa pakaian yang digunakan manusia tersebut adalah pakaian orang yang tidak mampu membeli pakaian yang layak dipakai. Sementara disisi yang lain, keringat yang menetes dari wajah manusia juga indeks yang menggambarkan kerja keras atau sedang dalam keadaan serius. Indeks keringat ini adalah petanda bahwa sang manusia yang digambarkan sedang atau habis bekerja keras mempertahankan hidupnya.

Visualisasi yang lain adalah balon raksasa yang menjadi tempat bergantungnya tali dimana manusia tersebut menggantungkan diri. Balon raksasa ini digambarkan berwarna hitam. Kontras dengan latar belakang gambar yang berwarna putih. Gambaran hitam pada balon adalah simbol budaya yang selalu diasosiasikan dengan kejahatan atau hal-hal yang jelek. Misalnya sosok hantu yang menakutkan digambarkan berwarna hitam. Gambaran hitam pada ikon balon adalah simbol kejahatan atau kezaliman yang membunuh atau mencekik leher manusia yang digambarkan.

Secara verbal gambar satu memperlihatkan dua caption. Caption pertama persis melekat pada kepala manusia yang digambarkan. Caption ini bertuliskan "rakyat". Sedangkan caption kedua dituliskan pada balon raksasa. Caption ini bertulisankan "BBM" dengan ukuran huruf yang besar. Sepert penjelasan terdahulu, caption ini berfungsi menegaskan visualisasi yang digambarkan. Dengan memberikan label atau caption pada masing-masing visual mempermudah atau membatu pembaca atau siapa saja yang melihat karikatur ini dalam mengarahkan asosiasinya. Jika 
kita hubungkan antara visulisasi dan caption, maka kita akan mendapatkan makna bahwa BBM yang melambung tinggi adalah hantu yang dapat membunuh masyarakat kecil.

4. Karikatur Suratkabar Pontianak Post, 7 Maret 2012

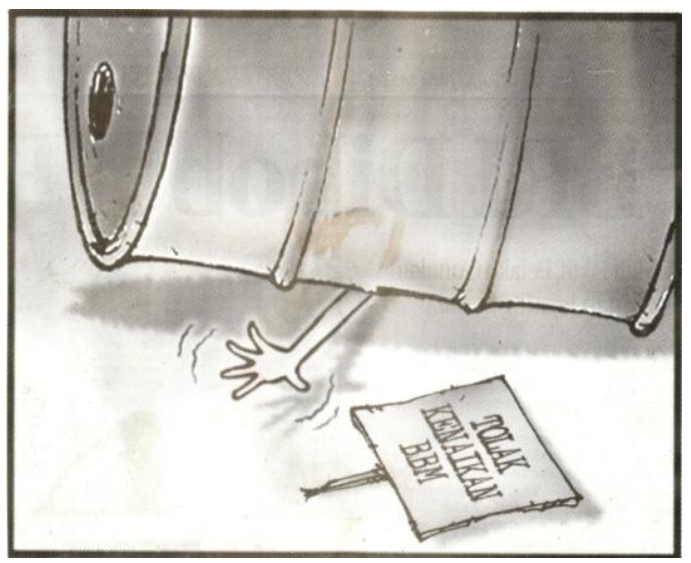

Sumber: Pontianak Post, Rabu 7 Maret 2012

Tabel 4. Sebaran Tanda pada Gambar 4

\begin{tabular}{|c|c|c|}
\hline Dimensi & $\begin{array}{l}\text { Ditandai } \\
\text { dengan }\end{array}$ & Asosiasi \\
\hline Icon & $\begin{array}{ll}\text { - } & \text { sebuah } \\
& \text { drum } \\
\text { - } & \text { tangan } \\
& \text { manusia } \\
\text { - } & \text { sebuah } \\
& \text { papan/plan } \\
\text { g nama }\end{array}$ & $\begin{array}{l}\text { Menyerupai } \\
\text { bentuk asli drum } \\
\text { Menyerupai } \\
\text { tangan manusia } \\
\text { Menyerupai } \\
\text { papan/plang } \\
\text { nama }\end{array}$ \\
\hline Indeks & $\begin{array}{ll}\text { - } & \text { tangan } \\
\text { manusia } \\
\text { yang } \\
\text { ceking atau } \\
\text { kurus } \\
\text { - jari tangan } \\
\text { yang } \\
\text { tebuka } \\
\text { lebar }\end{array}$ & $\begin{array}{l}\text { Penggambaran } \\
\text { orang kecil atau } \\
\text { orang miskin } \\
\text { Penggambaran } \\
\text { tangan } \\
\text { seseorang yang } \\
\text { sedang } \\
\text { kesakitan }\end{array}$ \\
\hline Simbol & $\begin{array}{ll}\text { - } & \text { Visualisasi } \\
& \text { kekelap- } \\
\text { gelapan } \\
\text { pada latar } \\
\text { - visualisasi } \\
\text { hitam pada }\end{array}$ & $\begin{array}{l}\text { Penggambaran } \\
\text { untuk } \\
\text { mendapatkan } \\
\text { kesan } \\
\text { menyeramkan } \\
\text { atau }\end{array}$ \\
\hline
\end{tabular}

\begin{tabular}{|l|l|l|}
\hline & drum & $\begin{array}{l}\text { menakutkan. } \\
\text { Penggambaran } \\
\text { untuk } \\
\text { mendapatkan } \\
\text { kesan } \\
\text { menyeramkan } \\
\text { atau } \\
\text { menakutkan. }\end{array}$ \\
\hline Caption & - TOLAK & Mengarahkan \\
& KENAIKAN & $\begin{array}{l}\text { bagaimana kita } \\
\text { harus berfikir } \\
\text { tentang wacana } \\
\text { kenaikan harga } \\
\text { bahan bakar } \\
\text { minyak. }\end{array}$ \\
\hline & &
\end{tabular}

Gambar 4 menghadirkan tiga visual. Pertama adalah sebuah drum yang digambarkan dalam posisi terbaring. Drum pada gambar ini digambarkan berwarna putih ke gelapgelapan. Tapi jika kita telah, lebih dominan gambaran hitam dari pada putihnya. Gambaran hitam pada drum adalah simbol sesuatu yang menakutkan, kejelekan atau hantu. Gambaran hitam ini bertujuan untuk mendapatkan efek mengerikan atau menakutkan. Gambar drum ini adalah ikon dari sebuah drum. Gambar drum secara paradigmatik dapat menghadirkan berbagai asosiasi. Drum dimaksud dapat bermakna tempat penyimpanan bensin, solar, minyak tanah, minyak goreng, air dan lain-lain. Jika dihubungkan dengan caption yang ada pada ikon papan nama di bawahnya, maka drum yang ada dalam gambar ini adalah drum tempat penyimpanan BBM.

Visualisasi kedua adalah sebelah tangan - sepertinya tangan kanan 
manusia yang posisinya tertelungkup ke tanah. Digambarkan pangkal tangan berada dibawah drum yang terbaring. Tangan tersebut digambarkan ceking atau kurus. Tangan yang kurus atau ceking merupakan indeks atau gambaran manusia yang kurang giji atau orang miskin. Secara kasat mata keseluruhan gambar menampilkan makna kesan bahwa ada seseorang yang sedang dihimpit atau tergilas oleh drum. Gambaran tangan pada gambar ini adalah ikon tangan manusia, yang seolah membutuhkan pertolongan.

Ketiga, sebuah papan nama dalam posisi roboh, atau tergeletak di tanah. Papan nama ini digambarkan berwarna putih, kegelap-gelapan. Pada papan nama tersebut tertulis caption "TOLAK KENAIKAN BBM". Gambaran papan nama ini adalah ikon dari sebuah papan nama, yang biasa digunakan untuk membuat papan nama sekretariat, kantor atau nama jalan dan lain-lain.

5. Karikatur Suratkabar Pontianak Post, 9 Maret 2012

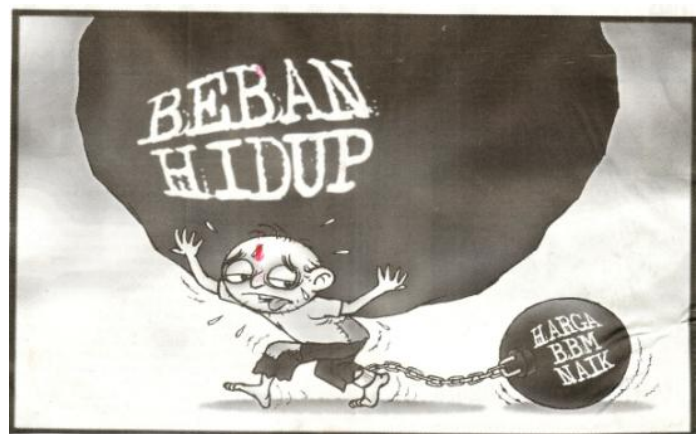

Sumber: Pontianak Post, Jum'at 9 Maret 2012
Tabel 5. Sebaran Tanda pada Gambar 5

\begin{tabular}{|c|c|c|}
\hline Dimensi & $\begin{array}{c}\text { Ditandai } \\
\text { dengan }\end{array}$ & Asosiasi \\
\hline Icon & $\begin{array}{ll}\text { - } & \text { seorang } \\
& \text { Manusia } \\
\text { - } & \text { bongkahan } \\
& \text { batu atau } \\
& \text { tanah } \\
- & \text { sebuag } \\
& \text { kerangkeng } \\
\text { besi }\end{array}$ & $\begin{array}{l}\text { Menyerupai } \\
\text { bentuk asli } \\
\text { manusia } \\
\text { Menyerupai batu } \\
\text { atau tanah } \\
\text { Menyerupai } \\
\text { kerangkeng besi }\end{array}$ \\
\hline Indeks & $\begin{array}{ll}\text { - } & \text { Wajah } \\
& \text { meringis; } \\
\text { - } & \text { lidah yang } \\
& \text { terjulur; } \\
\text { - } & \text { Pakaian } \\
& \text { yang } \\
& \text { bertambal; } \\
\text { - } & \text { Tetesan } \\
& \text { keringat; } \\
\text { - } & \text { Kaki yang } \\
& \text { tidak beralas } \\
\text { - badan yang } & \text { membungku } \\
& \text { k }\end{array}$ & $\begin{array}{l}\text { Penggambaran } \\
\text { seseorang yang } \\
\text { sedang } \\
\text { kesakitan } \\
\text { Penggambaran } \\
\text { seseorang yang } \\
\text { lagi sakit atau } \\
\text { kesakitan, atau } \\
\text { bahkan } \\
\text { meninggal } \\
\text { karena sakit } \\
\text { yang amat } \\
\text { pedih. } \\
\text { Penggambaran } \\
\text { orang } \\
\text { kecil/miskin } \\
\text { Penggambaran } \\
\text { seseorang yang } \\
\text { sedang bekerja } \\
\text { keras } \\
\text { Penggambaran } \\
\text { orang } \\
\text { kecil/orang tak } \\
\text { berpunya } \\
\text { Penggambaran } \\
\text { bada yang } \\
\text { sedang memikul } \\
\text { beban yang } \\
\text { berat }\end{array}$ \\
\hline Simbol & $\begin{array}{ll}\text { - } & \text { Visualisasi } \\
\text { kekelap- } \\
\text { gelapan } \\
\text { pada latar } \\
\text { visualisasi } \\
\text { hitam pada } \\
\text { bongkahan } \\
\text { batu } \\
\text { - visualisasi } \\
\text { hitam pada } \\
\text { kerangkeng } \\
\text { besi }\end{array}$ & $\begin{array}{l}\text { Penggambaran } \\
\text { untuk } \\
\text { mendapatkan } \\
\text { kesan } \\
\text { menyeramkan } \\
\text { atau } \\
\text { menakutkan. } \\
\text { Penggambaran } \\
\text { untuk } \\
\text { mendapatkan } \\
\text { kesan } \\
\text { menyeramkan } \\
\text { atau } \\
\text { menakutkan. } \\
\text { Penggambaran } \\
\text { untuk } \\
\text { mendapatkan } \\
\text { kesan } \\
\text { menyeramkan }\end{array}$ \\
\hline
\end{tabular}




\begin{tabular}{|c|c|c|}
\hline & & $\begin{array}{l}\text { atau } \\
\text { menakutkan }\end{array}$ \\
\hline Caption & $\begin{array}{l}\text { - BEBAN } \\
\text { HIDUP } \\
\text { - HARGA BBM }\end{array}$ & $\begin{array}{l}\text { Mengarahkan } \\
\text { bagaimana kita } \\
\text { harus berfikir } \\
\text { tentang wacana } \\
\text { kenaikan harga } \\
\text { bahan bakar } \\
\text { minyak. } \\
\text { Mengarahkan } \\
\text { bagaimana kita } \\
\text { harus berfikir } \\
\text { tentang wacana } \\
\text { kenaikan harga } \\
\text { bahan bakar } \\
\text { minyak. }\end{array}$ \\
\hline
\end{tabular}

Secara visual, gambar 5 manampilkan tiga tanda yang bisa diamati. Pertama, gambar manusia yang sedang memikul sebongkah batu. Digambarkan manusia ini seperti tertatihtatih karena sedang memikul sebongkah batu. Gambaran lain, manusia ini juga dalam keadaan terikat atau dikerangkeng pada pergelangan kakinya dengan rantai yang tersambung pada sebuah bola besi. Digambarkan pula bahwa dia tidak mengenakan alas kaki, sandal atau sepatu. Kaki yang tidak beralas adalah indeks yang menggambarkan orang kecil atau orang tak berpunya. Tetesan keringat digambarkan bertebaran disekitar wajahnya. Keringat yang mengucur adalah indeks dari badan yang sedang melakukan kegitan yang menguras tenaga. Gambar ini ingin menyampaikan pesan orang kecil atau orang tak berpunya sedang bekerja keras mempertahankan hidupnya. Gambar manusia ini adalah ikon dari seorang manusia. Ikon manusia yang sedang tertatih-tatih atau sedang dalam bekerja keras terlihat dari lidah yang menjulur keluar. Lidah yang menjulur adalah indeks yang menggambarkan respon tubuh atau terhadap tekanan atau himpitan. Dikaitkan dengan bongkahan batu yang dipkul, maka kita dapat memaknai bahwa badan sang manusia yang digambarkan sedang menahan himpitan yang luar biasa, sampai lidahnya terjulur.

Gambar kedua adalah bongkahan batu besar yang dipikul oleh seseorang. Bongkahan batu ini adalah ikon dari batu. Ketiga, gambar bola besi yang mengkarengkeng kaki manusia yang dihambarkan. Kerangkeng besi ini adalah ikon dari karengkeng bola besi yang terbuat dari besi yang diberi rantai sebagai pengikat manusia yang digambarkan. Digambarkan bongkahan batu ini berwarna hitam. Hitam adalah simbol budaya yang mencerminkan kekejaman, kejahatan dan sesuatu yang menakutkan, atau semua hal yang tidak baik. Gambar ini ingin menyampaikan makna bahwa sesuatu yang menakutkan itu sedang sedang menghimpit orang kecil yang ada pada gambar.

Bola besi yang dirantai dan mengikat pergelangan kaki seseorang dalam gambar ini adalah visualisasi ketiga. Kita sebut saja kerangkeng bola 
besi. Kerangkeng bola besi ini digambarkan berwarna hitam. Seperti di atas pemberian warna hitam untuk mendapatkan efek mengerikan atau menakutkan. Karena warna hitam secara budaya diasosiasikan dengan hal-hal yang megerikan atau menakutkan.

Secara verbal gambar 5 terdiri dari dua caption. Pertama, terdapat pada bongkahan batu yang dipikul oleh manusia yang digambarkan. Caption ini bertuliskan "BEBAN HIDUP". Ditulis dengan hurup kapital dan dan ukuran hurup yang besar. Pemberian hurup kapital dan ukuran hurup yang besar adalah pesan non verbal, bahwa agar menjadi fokus menarik perhatian pembaca. Selain itu warna putih pada hurup menandakan bahwa caption ini pentig untuk diperhatikan.

Caption yang kedua terdapat pada bola besi. Caption ini bertuliskan "HARGA BBM NAIK". Seperti caption pertama, caption kedua ini juga terdiri dari hurup kapital dan ukuran hurup yang besar. Tujuannnya untuk menarik perhatian pembaca.

Jika kita tutup atau kita buang kedua caption di atas, maka tanda hanya terdiri dari gambar telanjang. Gambar telanjang biasanya bias, multi tafsir. Sehingga banyak asosiasi yang kemungkinan bisa dilekatkan pada gambar. Dengan memberikan caption, karikatur ini mengarahkan bagaimana pembaca harus menafsirkan teks. Jadi, caption berfungsi membantu pembaca memaknai teks, yang dalam konteks ini adalah teks karikatur. Sehingga, gambar tidak lagi multi tafsir atau bias. Caption dengan demikian mengikat pembaca harus berfikir seperti apa tentang teks.

\section{B. Kesimpulan}

Berdasarkan analisis di atas tulisan menyimpulkan bahwa karikatur Suratkabar Pontianak Post mengenai wacana kenaikan harga bahan bakar minyak menggambarkan atau mencitrakan: 1). Kenaikan harga BBM adalah penderitaan bagi masyarakat kecil; 2). Kenaikan harga BBM menyebabkan kenaikan harga-harga; 3). Kenaikan harga BBM harus dilawan; dan 4). Penguasa tidak memiliki sense of crisis.

Ideologi demokrasi diyakini mempengaruhi teks karikatur suratkabar Pontianak Post dalam mewacanakan rencana pemerintah untuk menaikan harga bahan bakar minyak. Karena, dengan ideologi demokrasi yang mereka anut memungkinkan mereka untuk memilih atau bersikap berseberangan atau mengambil sikap "konfrontasi" terhadap rencana pemerintah SBY untuk menaikkan harga bahan bakar minyak. Hal ini tampak dari gambaran pada 
karikatur, yang mencerminkan sikap mereka yang tidak setuju terhadap rencana tersebut. Bahkan di antaranya ada yang terkesan menghasut masyarakat untuk berkonfrontasi terhadap rencana pemerintah atau penguasa untuk menaikkan harga bahan bakar minyak di awal tahun 2012.

\section{Daftar Pustaka}

Agus Sudibyo, 2001. Politik Media dan Pertarungan Wacana, Jakarta: LKiS;

Arthur Asa Berger, 1991. Media Analysis Techniques, resived edition, Beverly Hills : Sage Publication;

Kurniawan, 2001. Semiologi Roland Barthes, Magelang: Indonesia Tera;

Roland Barthes, 2012. Imagi, Musik, Teks; Analisis Semiologi atas Fotografi, Iklan, Film, Musik, alkitab, Penulisan dan Pembacaan serta Kritik sastra, (terj: Agustinus Hartono, Yogyakarta: Jalasutra;

Suratkabar Pontianak Post, edisi Kamis, 1 Maret 2012;

Suratkabar Pontianak Post, edisi Sabtu, 3 Maret 2012;

Suratkabar Pontianak Post, edisi Selasa, 6 Maret 2012;

Suratkabar Pontianak Post, edisi Rabu, 7 Maret 2012;
Suratkabar Pontianak Post, edisi Jum'at, 9 Maret 2012; 